\title{
Techno-environmental assessment of the green biorefinery concept: Combining process simulation and life cycle assessment at an early design stage
}

Corona, Andrea; Ambye-Jensen, Morten; Vega, Giovanna Croxatto; Hauschild, Michael Zwicky; Birkved, Morten

Published in:

Science of the Total Environment

Link to article, DOI:

10.1016/j.scitotenv.2018.03.357

Publication date:

2018

Document Version

Version created as part of publication process; publisher's layout; not normally made publicly available

Link back to DTU Orbit

Citation (APA):

Corona, A., Ambye-Jensen, M., Vega, G. C., Hauschild, M. Z., \& Birkved, M. (2018). Techno-environmental assessment of the green biorefinery concept: Combining process simulation and life cycle assessment at an early design stage. Science of the Total Environment, 635, 100-111.

https://doi.org/10.1016/j.scitotenv.2018.03.357

\section{General rights}

Copyright and moral rights for the publications made accessible in the public portal are retained by the authors and/or other copyright owners and it is a condition of accessing publications that users recognise and abide by the legal requirements associated with these rights.

- Users may download and print one copy of any publication from the public portal for the purpose of private study or research.

- You may not further distribute the material or use it for any profit-making activity or commercial gain

- You may freely distribute the URL identifying the publication in the public portal 


\title{
Techno-environmental assessment of the green biorefinery concept: Combining process simulation and life cycle assessment at an early design stage
}

\author{
Andrea Corona $^{\mathrm{a}, *}$, Morten Ambye-Jensen ${ }^{\mathrm{b}}$, Giovanna Croxatto Vega ${ }^{\mathrm{a}}$, Michael Hauschild ${ }^{\mathrm{a}}$, Morten Birkved ${ }^{\mathrm{a}}$ \\ a Division for Quantitative Sustainability Assessment, Department of Management Engineering, Technical University of Denmark, Bygningstorvet, 2800 Lyngby, Denmark \\ ${ }^{\mathrm{b}}$ Department of Engineering, Aarhus University, Hangøvej 2, 8200 Aarhus, Denmark
}

\section{A R T I C L E I N F O}

\section{Article history:}

Received 3 January 2018

Received in revised form 28 March 2018

Accepted 29 March 2018

Available online $\mathrm{xxx}$

Editor: Simon Pollard

\section{Keywords:}

LCA

Process simulation

GBR

Biorefinery

Sustainability

\begin{abstract}
A B S T R A C T
The Green biorefinery (GBR) is a biorefinery concept that converts fresh biomass into value-added products The present study combines a Process Flowsheet Simulation (PFS) and Life Cycle Assessment (LCA) to evaluate the technical and environmental performance of different GBR configurations and the cascading utilization of the GBR output. The GBR configurations considered in this study, test alternatives in the three main steps of green-biorefining: fractionation, precipitation, and protein separation. The different cascade utilization alternatives analyse different options for press-pulp utilization, and the LCA results show that the environmental profile of the GBR is highly affected by the utilization of the press-pulp and thus by the choice of conventional product replaced by the press-pulp. Furthermore, scenario analysis of different GBR configurations shows that higher benefits can be achieved by increasing product yields rather than lowering energy consumption. Green biorefining is shown to be an interesting biorefining concept, especially in a Danish context. Biorefining of green biomass is technically feasible and can bring environmental savings, when compared to conventional production methods. However, the savings will be determined by the processing involved in each conversion stage and on the cascade utilization of the different platform products.
\end{abstract}

(C) 2017 .

\section{Introduction}

In recent years, the utilization of biomass for the production of feed, fuel and fibers has been suggested as one of the most promising solutions to fight climate change and reduce our dependence on petroleum derivatives. Several strategies have been proposed for the upgrade of biomass feedstock into a large array of products. Initial research, focusing on the utilization of food crops for the production of biofuels showed the technology to be technically and economically feasible (Worldwatch Institute, 2006). However, concerns were quickly raised regarding competition for land (i.e. the "food vs fuel dilemma") (OECD, 2008) and environmental savings, in comparison to traditional fossil fuels, were shown to be small (if any) when land use changes were included in the environmental sustainability assessment (Fargione et al., 2008; Searchinger et al., 2008). Since then, interests have shifted to the utilization of non-edible crops and crop residues in biorefineries: the so-called second-generation feedstocks. The goal of a biorefinery is to utilize all biomass fractions in order to maximize the product yield per biomass input, in the same way conventional refineries have been optimized to produce a multitude of products by exploiting all the crude oil components.

Biorefineries can be classified depending on the type of biomass feedstock they use (Bell et al., 2014; Cherubini et al., 2009; Kamm, 2013). The most prominent biorefinery concepts are: "yellow" biorefineries that utilize "dry" lignocellulosic materials; "green" biore-

\footnotetext{
* Corresponding author.

Email address: corona@dtu.dk (A. Corona)
}

fineries that utilize nature's "wet" grasses and immature crops; "blue" biorefineries that use algae; and "grey" biorefineries that utilize food waste.

Of particular interest, especially for the Danish context, is the green biorefinery. The green biorefinery aims at exploiting certain biomass components, which are generally lost during the maturation or drying of the biomass. Those components are generally water-soluble compounds, which become hard to fractionate when water is removed from the plant cell. The green biorefinery generally fractionates a "wet" biomass into a liquid stream and a solid stream (Xiu and Shahbazi, 2015). From these two streams, different cascading products can be generated depending on the processes involved (Kromus et al., 2006).

Three aspects make the green biorefinery concept interesting for the Danish scenario, as it can:

1) Decrease import dependency on protein-rich feed for the extensive Danish livestock sector.

2) Stimulate the local agricultural sector.

3) Increase synergies between different agricultural sectors (i.e. pig and poultry husbandry, dairy production and crop farming).

Due to intensive livestock production in Denmark, approximately 36 million tons of feed-products were consumed in 2015. While roughage and cereals are almost entirely produced in Denmark, approximately $80 \%$ of the protein-rich feed is imported (Bosselmann et al., 2015), and local production consists mainly of rape cakes and other by-products from the food industry. Soya by-product imports (cakes) account for approximately $50 \%$ of the total protein-rich feed consumption and $62 \%$ of the total import of protein-rich feed. Soya is 
imported mainly from South America directly, or re-exported from other EU countries, and a minor import comes from USA (Termansen et al., 2016). Fig. SI-5 in the Supporting Information (SI) shows the soy-based feed import to Demark in 2015. Due to socio-political concerns and environmental problems connected to soy production, as well as the added benefit of not paying for soya imports (Cong and Termansen, 2016), there is an active interest to reduce import dependency and look for local alternative protein sources (Hörtenhuber et al., 2011; Lehuger et al., 2009). In the SI, Table SI-17 presents the consumption of the most important protein-rich feed in Demark between 2010 and 2015.

The second aspect is the intensification of Danish agriculture. Cereals occupy a majority of Danish farmland and knowhow on cereal cultivation is estimated to be already at its maximum. Thus, limited improvement can be achieved in countries where intensive farming is already practiced. Annual crops such as cereals cannot use a significant part of the solar radiation during the growing season for photosynthesis and biomass production. Cereal crops mature from mid-July, are harvested in August, are re-sown in September and green fields are not seen until the very end of the year (Termansen et al., 2016). Grasses on the contrary, are perennial crops that can utilize solar radiation available year-round, achieving higher DM yields on a yearly basis (Gylling et al., 2016). Having a permanent soil cover, not only allows for higher yields, but can also bring benefits by minimizing nutrient losses. Eriksen et al. (2014) compiled a catalogue of measures, which may be used to mitigate nitrogen leaching in Denmark. In this context, the conversion of land from cereals to permanent intensive grass has been suggested as a relevant mitigating measure. In addition to reductions of nitrogen leaching, the transition from annual crops to perennial crops is also expected to lead to an increase in the carbon stock in the soil, due to the larger root system, and it will also lead to a decrease in the pesticide use compared to cereals (Jørgensen and Lærke, 2016).

Finally, the green biorefinery concept could improve synergies between pig and poultry farmers, dairy farmers and crop producers, on the one hand developing alternative and local protein sources and on the other intensifying the use of arable land (Cong et al., 2017; Gylling et al., 2016).

Given the potential of GBR to bring benefits across sectors, several projects have focused on developing the technology. Despite the common basic technology, i.e. fractionation of a wet feedstock into a liquid and a solid fraction, different process configurations and different target products have been developed, see Table 1. Several

Table 1

Overview of the different GBRs concepts developed in Europe.

\begin{tabular}{|c|c|c|c|c|}
\hline Country & $\begin{array}{l}\text { Product } \\
\text { from cake }\end{array}$ & $\begin{array}{l}\text { Product } \\
\text { from juice }\end{array}$ & $\begin{array}{l}\text { Product from } \\
\text { residuals }\end{array}$ & Reference \\
\hline Netherlands & $\begin{array}{l}\text { Ruminant } \\
\text { feed }\end{array}$ & $\begin{array}{l}\text { Protein } \\
\text { feed }\end{array}$ & Biogas & www.grassa.nl \\
\hline Germany & Feed pellets & $\begin{array}{l}\text { Protein } \\
\text { feed/food }\end{array}$ & Biogas & (Kamm et al., 2010) \\
\hline Germany & $\begin{array}{l}\text { Composite } \\
\text { material }\end{array}$ & $\begin{array}{l}\text { Protein } \\
\text { feed }\end{array}$ & Fertilizer & www.biowert.de \\
\hline Switzerland & $\begin{array}{l}\text { Composite } \\
\text { material }\end{array}$ & Biogas & Biogas & $\begin{array}{l}\text { (Sharma and Mandl, } \\
\text { 2014) }\end{array}$ \\
\hline Austria & Biogas & $\begin{array}{l}\text { Lactic acid } \\
\text { Amino } \\
\text { acid }\end{array}$ & Biogas & (Ecker et al., 2012) \\
\hline Ireland & $\begin{array}{l}\text { Composite } \\
\text { material }\end{array}$ & $\begin{array}{l}\text { Protein } \\
\text { feed } \\
\text { Lactic } \\
\text { acid }\end{array}$ & Biogas & (O'Keeffe et al., 2012) \\
\hline Denmark & Silage Feed & $\begin{array}{l}\text { Protein } \\
\text { feed }\end{array}$ & Biogas & $\begin{array}{l}\text { (Ambye-Jensen and } \\
\text { Adamsen, 2015) }\end{array}$ \\
\hline Denmark & $\begin{array}{l}\text { Grass } \\
\text { pellets }\end{array}$ & Lysine & Lysine & $\begin{array}{l}\text { (Andersen and Kiel, } \\
2000 \text { ) }\end{array}$ \\
\hline
\end{tabular}

techno-economical assessments have been published, suggesting that the GBR could be feasible and economically competitive (Kamm et al., 2016; O'Keeffe et al., 2012; Sinclair, 2009). However, until now, knowledge on the best configuration remains limited, due to limited penetration and implementation in the biorefinery market. Furthermore, few studies have looked at the environmental sustainability of the GBR system (Cong and Termansen, 2016; Corona et al., n.d.; Parajuli et al., 2017a) and none have focused on finding the most sustainable GBR value-chain.

Therefore, the present study performs a techno-environmental assessment of different GBR configurations. In order to estimate the technical performance of different GBRs, at an early design stage, a Process Flowsheet Simulation (PFS) of different GBR configurations was developed. The PFS, based on experiments and production trials performed at a pilot plant in (Foulum, DK), estimates material and energy input, as well as quantity and quality of the products for each configuration. The PFS's results were used to populate the inventory of the LCA model, in order to screen the best configuration in terms of environmental performance, to identify hotspot and focus points for the technology developers within the conversion pathway. Finally, a sensitivity analysis was used to look at the effect of process optimization on the environmental performance of the GBR.

\section{Materials and methods}

\subsection{Description of the green biorefinery}

A GBR pathway can be described in five main steps:

1) Biomass cultivation

2) Fractionation

3) Precipitation

4) Protein separation

5) Downstream processing of the GBR output

A general description of each step is presented in the following paragraphs. Additional information is available in the SI.1. The studied GBR has a capacity of 20,000 ton $_{\mathrm{DM}} / \mathrm{yr}$, and is assumed to operate between May and October. Data for the different processes in the GBR, as well as estimates of a realistic process optimization, were obtained from experiments and production trials performed at a pilot plant facility at Aarhus University, located in Foulum, Denmark (Hermansen et al., 2017). Energy consumption for each process in the GBR value-chain is presented in Table 2. Data for alternative cascade

Table 2

Energy consumption of the different biorefinery processes.

\begin{tabular}{|c|c|c|c|}
\hline Process & Unit & Energy & Source \\
\hline Shredder & $\mathrm{kWh} /$ ton $_{\mathrm{DM}}$ & 20 & BioValue \\
\hline Fractionation & $\mathrm{kWh} /$ ton $_{\mathrm{DM}}$ & 11.1 & BioValue \\
\hline Anti-foaming agent & $\mathrm{Kg} / \mathrm{m}^{3}$ press-juice & 1 & BioValue \\
\hline Thermal precipitation & $\mathrm{MJ} / \mathrm{m}_{\text {press- }}$ & 294 & BioValue \\
\hline Pumping & $\begin{array}{l}\text { juice } \\
\mathrm{kWh} / \mathrm{m}_{\text {press- }}^{3}\end{array}$ & 1 & BioValue \\
\hline Biological precipitation & $\mathrm{MJ}^{\text {juice }} \mathrm{m}_{\text {press- }}^{3}$ & 84 & BioValue \\
\hline Centrifugation & $\mathrm{kWh} / \mathrm{m}_{\text {press- }}^{3}$ & 11 & BioValue \\
\hline Drying heat $(35 \%-60 \% \mathrm{DM})$ & $\begin{array}{l}\text { juice } \\
\mathrm{MJ} / \text { ton }_{\text {water }}\end{array}$ & 2000 & $\begin{array}{l}\text { (Grabowski and Boye, } \\
\text { 2012; Mujumdar, 2014) }\end{array}$ \\
\hline Drying heat $(60 \%-95 \% \mathrm{DM})$ & $\mathrm{MJ} /$ ton $_{\text {water }}$ & 5000 & $\begin{array}{l}\text { (Grabowski and Boye, } \\
\text { 2012; Mujumdar, 2014) }\end{array}$ \\
\hline Drying electricity & $\mathrm{kWh} /$ ton $_{\text {product }}$ & 2.64 & $\begin{array}{l}\text { (Grabowski and Boye, } \\
\text { 2012; Mujumdar, 2014) }\end{array}$ \\
\hline $\begin{array}{l}\text { Human-grade protein } \\
\text { separation and drying }\end{array}$ & $\mathrm{kWh} /$ ton $_{\text {product }}$ & 428 & (Kamm et al., 2009) \\
\hline
\end{tabular}


utilization of the press-pulp and for the production of human-grade protein were based on values taken from literature (Kamm et al., 2009; Kromus et al., 2004).

\subsubsection{Feedstock}

Alfalfa (Medicago sativa) was assumed to be a representative feedstock for the GBR process, as it is one of the most important foraging crops in Europe, covering 7.12 million ha in 2010 (Kamm et al., 2016). The inventory for the cultivation of alfalfa in Denmark and transportation to the biorefinery gate was based on Parajuli et al. (2017b). Alfalfa is assumed to be a rotational crop, with a rotation cycle of three years and three harvests per year (Jørgensen et al., 2011). Yearly yield of alfalfa was assumed to be $12 \operatorname{ton}_{\mathrm{DM}} /$ year. The complete inventory for the agricultural stage of alfalfa is available in the supporting information, SI-2.1.

\subsubsection{Fractionation}

The fractionation step aims at separating the liquid stream i.e. the press-juice, from the solid fiber-rich fraction, i.e. the press-pulp. The biomass is initially shredded and fed into a screw-press were it is mechanically separated into the liquid and solid stream. The fractionation step can be performed once or twice, with a washing step in-between. In this study, the baseline consists of a single-step pressing. As an alternative, after the first pressing, water is added to the press-pulp to achieve a $25 \%{ }_{\mathrm{DM}}$ concentration, which is then re-pressed, resulting in a two-step pressing (O'Keeffe et al., 2011b). The latter allows for a higher extraction of soluble components, proteins and carbohydrates. One-step pressing has a protein extraction efficiency of $45 \%$, while with a two-step pressing the overall extraction efficiency can be increased to $65 \%$ (DCA, 2016). After the fractionation stage, the two streams are separated and sent to the following downstream processes.

\subsubsection{Press-pulp utilization}

The press-pulp- or fiber-rich fraction- mainly contains the insoluble components of the biomass. This fraction is rich in structural carbohydrates, predominantly cellulose, and contains the fiber-bound proteins, as well as residual non-separated soluble proteins. This study analysed three different cascade utilizations for the press-pulp. Studied utilizations include:

1) Use as ruminant feed

2) Use as composite material for insulation

3) Use as feedstock for lysine production

\subsubsection{Utilization as ruminant feed}

In this scenario, the press-pulp is ensiled and used as animal feed. The scenario aims at utilizing the carbohydrates and fiber-bound protein content as feed for ruminants, which requires that the press-pulp is ensiled and stored for further use. When utilized as ruminant feed, the press-pulp must meet a minimum protein content requirement of $140 \mathrm{~g} / \mathrm{kg}$ DM of the dried press cake (Kamm et al., 2010). The ensiled press-pulp is assumed to replace alfalfa silage.

\subsubsection{Utilization as composite material for insulation}

This scenario aims at utilizing press-pulp fibers in thermal insulation panels. The press-pulp is initially dried to reach a DM content of $92 \%$. Subsequently, the dried fibers are mixed with Borax to increase fire resistance, and be compliant with current fire and safety standards for buildings. The product is assumed to enter the insulation material market and replaces other conventional insulation panels e.g. panels made from mineral wool. Inventory for this scenario is based on (Biowert, 2014; Kamm et al., 2009; Kromus et al., 2006, 2004).

\subsubsection{Utilization as fermentation feedstock}

This scenario aims at exploiting the carbohydrate content of the press-pulp by producing sugars for downstream fermentation processes. The targeted fermentation product is lysine. The press-pulp first undergoes a hydrothermal pre-treatment to break down the biomass structure. The biomass is subsequently treated with enzymes, to induce hydrolysis of the carbohydrates into shorter-chain sugars that can be metabolized by yeast or bacteria during the fermentation process. The sugars from the hydrolyzed press-pulp are used as carbon source for the fermentation organisms, replacing the conventional carbon source used in lysine production, which is glucose syrup (Anaya-Reza and Lopez-Arenas, 2017; Blonk Consultant, 2010; Leiß et al., 2010). Inventory for this scenario is based on (Bentsen et al., 2006; Blonk Consultant, 2010; Larsen et al., 2012; Wang et al., n.d.).

\subsubsection{Press-juice utilization}

The press-juice contains most of the soluble content of the original biomass, such as soluble carbohydrates and protein. Depending on the targeted compound i.e. generally the soluble proteins, different downstream processes can be used for separation from the press-juice. The proteins are precipitated from the press-juice to facilitate the separation and are subsequently dried, while the residual press-juice is sent to the biogas plant for anaerobic digestion.

\subsubsection{Protein precipitation from press-juice}

Two different precipitation methods have been included in the model, thermal and biological precipitation. During thermal precipitation, the press-juice is heated to $80^{\circ} \mathrm{C}$ by steam and heat exchangers. At this temperature, proteins denature and coagulate into larger agglomerates that will settle or float in the supernatant surface. Alternatively, precipitation can be induced by lowering the $\mathrm{pH}$ of the solution. In this scenario, lactic acid bacteria are inoculated in the press-juice, which acidifies the fermentation solution and brings the $\mathrm{pH}$ down to 4 to make the proteins coagulate (Santamaría-Fernandez et al., 2017). This second scenario has lower energy needs, but also a lower precipitation efficiency.

\subsubsection{Protein separation}

For the protein separation process two main process set-ups have been included in the model. In the baseline scenario, a simple decanter centrifuge separates the protein from the press-juice (Termansen et al., 2016). The resulting product has a protein content of approximately $46-50 \%$ DM, which can be used as protein-rich feed for monogastric animals (e.g. pigs) in substitution of other protein-rich feed and has a similar composition and protein content to soybean meal (Kragbæk, 2014). The combined protein extraction efficiency from both the decanter centrifuge and thermal or biological precipitation processes ranges from $90 \%$ if thermal precipitation is used to $70 \%$ for the biological precipitation.

An alternative scenario has been proposed by Kamm et al. (2016), where two different protein products are produced; an "animal-grade" protein-rich feed that can be used for monogastric animals; and a "human-grade" protein-rich food that has higher quality and purity, and can be used by humans. This two-step process requires milder heating, at $60^{\circ} \mathrm{C}$, in the precipitation stage and cannot be performed with biological precipitation. In the first stage, the animal-grade protein is separated by centrifugation, with a protein separation efficiency of $70 \%$. The quality of this feed is similar to the protein-rich feed of the baseline protein separation process. In the second stage, the human-grade protein is separated from the remaining liquid stream by acid precipitation and membrane filtration. Protein separa- 
tion efficiency of this second step is $90 \%$ of the available protein in the residual press-juice.

\subsubsection{Drying}

After the separation process, the animal grade protein product has a DM content of approximately $34 \%$ and the human grade protein product a DM content of approximately $24 \%$. All products are dried until a $95 \%$ DM content is achieved. A drying step has yet to be implemented at the pilot plant at AU Foulum. Estimates of energy consumption for this step are therefore based on general energy usage in industrial water removal operations, as reported in the literature (Grabowski and Boye, 2012; Mujumdar, 2014), as well as on communications with the green pellet industry in Denmark (Dangrønt products A/S). The estimated energy consumption is divided into two steps, (i) from 35 to $60 \% \mathrm{DM}$ and (ii) from 60 to $95 \% \mathrm{DM}$, due to differences in efficiency of moisture removal at lower dry matter concentrations. It is thereby estimated that $2000 \mathrm{~kJ} / \mathrm{kg}$ of evaporated water are used for the first stage and $5000 \mathrm{~kJ} / \mathrm{kg}$ for the second stage. Furthermore, it is estimated that the consumption from external energy sources in the future may be reduced by a factor of five to ten. This estimated energy optimization would be a result of e.g. process development, heat integration with energy production such as biogas, and mixing the wet product with other dried feed ingredients, which would aid the subsequent drying process. (Grabowski and Boye, 2012). In the model's baseline, a semi-industrial scale of the process is represented by assuming a fivefold reduction of heat consumption, and $50 \%$ of the heat used in the drying process is recycled in the system from drying to precipitation (Grabowski and Boye, 2012; Mujumdar, 2014). The influence of heat optimization is further analysed in the sensitivity analysis, Section 2.2.4.

\subsubsection{Utilization of the residual juice}

The deproteinated press-juice still contains valuable organic compounds that can be fermented by anaerobic digestion in a biogas plant. The amount of biogas produced by the residual fraction was estimated using Buswell's formula (Buswell and Mueller, 1952), assuming a biogas conversion efficiency of $70 \%$, in a hypothetical 2-stage wet mesophilic anaerobic digestion plant (Hamelin et al., 2014). The biogas produced is supplied to a combined heat and power engine (CHP) with an electrical efficiency of $\eta=40 \%$ and thermal efficiency of $\eta=45 \%$ (O'Keeffe et al., 2011b). The digestate was assumed to be subsequently spread on the field within the catchment area supplying the GBR, hence avoiding the production of conventional fertilizers (O'Keeffe et al., 2011a). Calculation of the fertilizer potential of the digestate was taken from (O'Keeffe et al., 2011b) and adapted to the selected biomass, based on its biochemical composition of the deproteinated press-juice.

\subsection{LCA model description}

\subsubsection{Goal and scope definition}

This study aims to compare different GBR configurations at the early stages of biorefinery design. Furthermore, the study attempts to answer the research questions: "What are the environmental impacts connected to different GBR configurations?" and "What is the best utilization for the press-pulp and press-juice?" To answer these specific questions, the functional unit selected for the analysis is the "Production and conversion of 1 ton $_{D M}$ of alfalfa biomass in the GBR". Thus, the LCA can be used to estimate the environmental impacts associated with the production and conversion of the feedstock, while using different GBR configurations and/or targeting different final products. In Table 3, an overview of the different scenarios tested in the PFS and LCA model is presented.
Table 3

Overview of the tested scenarios in the PFS and LCA model. Configuration scenarios are indicated with a number, while utilization scenarios are indicated with a letter.

\begin{tabular}{|c|c|c|c|c|}
\hline Scenario name & Pressing & Precipitation & $\begin{array}{l}\text { Protein } \\
\text { separation }\end{array}$ & $\begin{array}{l}\text { Solid fraction } \\
\text { utilization }\end{array}$ \\
\hline $\begin{array}{l}\text { Baseline } \\
\text { (1.T.1.S) }\end{array}$ & 1step & Thermal & 1step & Feed \\
\hline 1.T.1.F $\mathrm{F}^{\mathrm{a}}$ & 1step & Thermal & 1step & Fermentation \\
\hline 1.T.1C & 1step & Thermal & 1step & Composite \\
\hline 1.T.2.S & 1step & Thermal & 2Step & Feed \\
\hline 1.T.2.F & 1step & Thermal & 2Step & Fermentation \\
\hline 1.T.2.C & 1step & Thermal & 2Step & Composite \\
\hline 1.B.1.S & 1step & Biological & 1Step & Feed \\
\hline 1.B.1.F & 1step & Biological & 1step & Fermentation \\
\hline 1.B.1.C & 1step & Biological & 1step & Composite \\
\hline 2.T.1.S & 2Step & Thermal & 1Step & Feed \\
\hline 2.T.1.F & 2Step & Thermal & 1Step & Fermentation \\
\hline 2.T.1.C & 2Step & Thermal & 1Step & Composite \\
\hline 2.T.2.S & 2Step & Thermal & 2Step & Feed \\
\hline 2.T.2.F & 2Step & Thermal & 2Step & Fermentation \\
\hline 2.T.2.C & 2Step & Thermal & 2Step & Composite \\
\hline 2.B.1.S & 2Step & Biological & 1Step & Feed \\
\hline 2.B.1.F & 2Step & Biological & 1Step & Fermentation \\
\hline 2.B.1.C & 2Step & Biological & 1Step & Composite \\
\hline
\end{tabular}

a The abbreviations used as scenario names signify $(\mathrm{x}, \mathrm{T}, \mathrm{y}, \mathrm{F})$ : were $\mathrm{x}$ indicates the number of pressing step (one or two), the middle letter indicates the type of precipitation process used ( $\mathrm{T}$ thermal, B biological), y indicates the separation steps (one or two), and the last letter indicates the solid fraction utilization ( $\mathrm{S}$ silage, $\mathrm{C}$ composites, $\mathrm{F}$ fermentation).

\subsubsection{System boundaries and life cycle inventory data}

The system was analysed from cradle to biorefinery exit gate. Fig. 1 shows the system boundary and the unit processes included in the analysis. The system was expanded to include the substitution of conventional products by the GBR products. The PFS model calculated the inventory for biomass conversion in the biorefinery in terms of product yields and quality, and consumption of energy and auxiliary materials, while the EcoInvent 3 life cycle unit process database (Wernet et al., 2016) was used to supply the background data.

\subsubsection{Environmental impact categories and the LCA methods}

The environmental impact categories used in this study are: Global Warming Potential (GWP), Eutrophication Potential (EP), Non-Renewable Energy (NRE) use, Agricultural Land Occupation (ALO), and Potential Freshwater Ecotoxicity (PFWTox). The selection of the environmental Impact Categories considered in this study was based on Parajuli et al. (2015) and to be in line with the LCA data used for the cultivation stage provided by (Parajuli et al., 2017b), which is used in this assessment. For the first three impact categories (ICs) the "EPD" method (Environdec, 2015) was used. For the calculation of climate change impacts, the contributions from indirect land use changes (ILUC) induced by the occupation of arable land for the production of the biomass and those avoided by the displaced conventional products, were also included. ILUC factor was taken from Schmidt et al. (2015). The ReCiPe method (Huijbregts et al., 2015) was used to estimate agricultural land occupation impacts, while the ILCD method (JRC, 2011) was used for the PFWTox impacts.

\subsubsection{Sensitivity analysis}

In the sensitivity analysis, the parameters connected to the heat optimization, which has not been implemented at the pilot plant yet, were varied in the GBR model to observe the effects of different plant maturity levels on the NRE impact score. The effect of optimization values from 1 to 10 and heat recycling from $0 \%$ to $100 \%$ were evaluated in the baseline scenario. This allows simulating the biorefinery at different optimization/maturity levels: from a non-opti- 


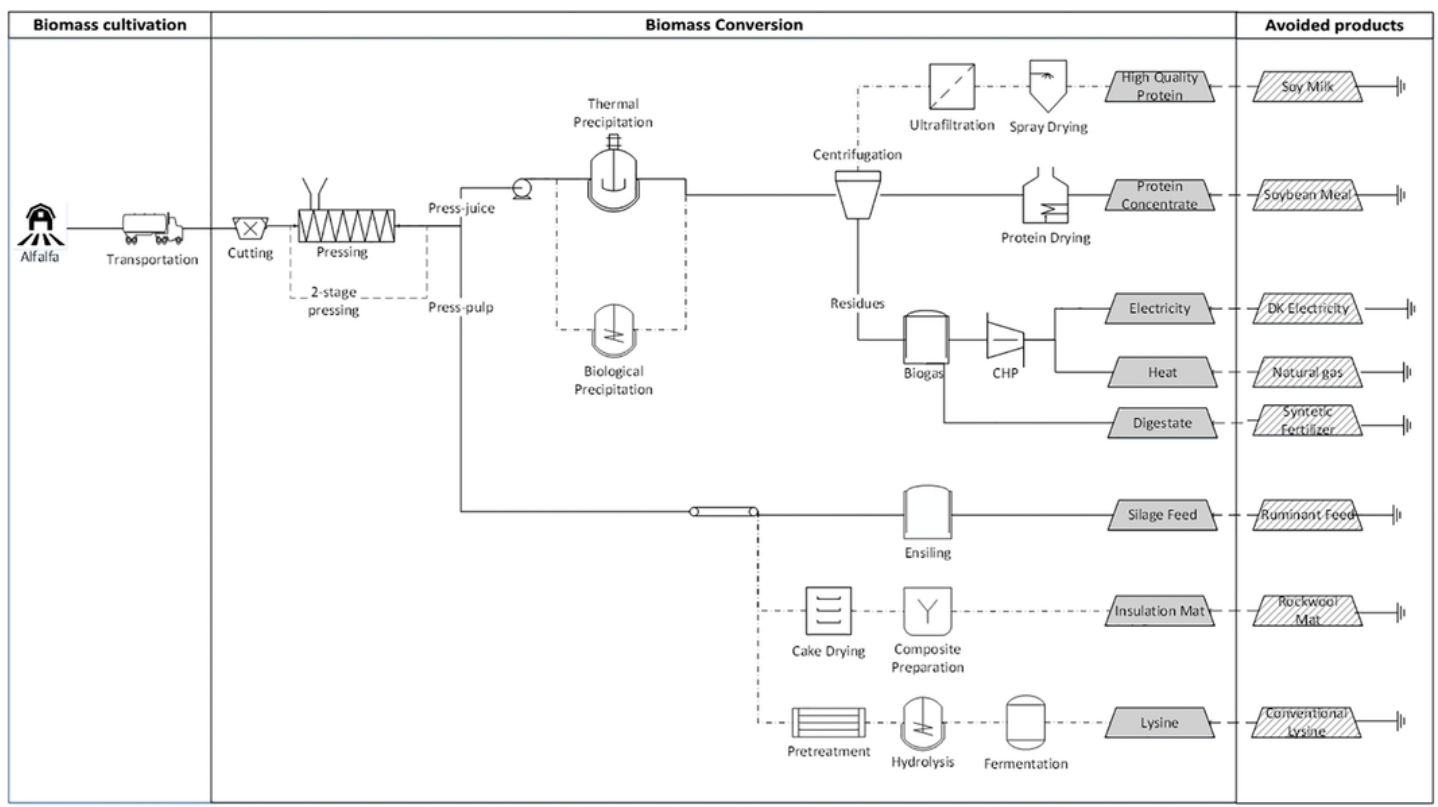

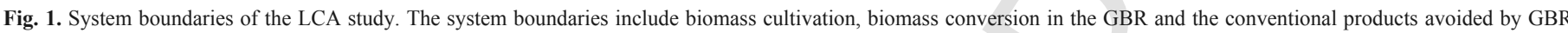

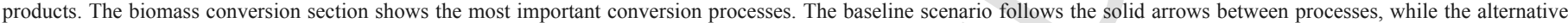
scenarios are identified with dotted lines. Dark grey boxes show the GBR products while white dashed boxes show the avoided products displaced by the GBR products.

mized/lab-scale level (optimization $=1$, recycling $0 \%$ ) to semi-industrial/pilot plant (optimization $=5$; heat recycling $=50 \%$ ) and finally to optimized/industrial level (optimization $=10$, recycling $=100 \%$ ) calculated after Kamm et al. (2016).

\subsubsection{Substitution factor}

Each of the GBR products is assumed to replace a conventional product. To estimate the impact due to the avoided production of conventional products, substitution factors were calculated based on the individual product's quality and the market that the GBR products enter. Table 4 shows the conventional products replaced by the GBR products and the basis for calculating the substitution factor. SI-2.3 describes how the substitution factors were calculated.

\section{Results and discussion}

\subsection{Process flowsheet simulation results}

\subsubsection{Product yield and composition}

The PFS model was used to estimate the quantity and composition of the GBR's outputs, as well as energy and auxiliary materials consumption in the GBR. Results are calculated for the conversion of

Table 4

Overview of the conventional products replaced by the GBR output. The last column lists the property for which the substitution factor is calculated. Details of the calculation of the substitution factor are presented in SI-2.3.

\begin{tabular}{|c|c|c|}
\hline GBR Product & Replaced product & Substitution factor \\
\hline Animal-grade protein & Soybean meal & $\begin{array}{l}\text { Nutritional Value (digestible protein } \\
\text { content) }\end{array}$ \\
\hline Human-grade protein & Soymilk & $\begin{array}{l}\text { Nutritional Value (digestible protein } \\
\text { content) }\end{array}$ \\
\hline Feed from press-pulp & Alfalfa silage & $\begin{array}{l}\text { Nutritional Value (digestible energy } \\
\text { content) }\end{array}$ \\
\hline $\begin{array}{l}\text { Composite from } \\
\text { press-pulp }\end{array}$ & $\begin{array}{l}\text { Rockwool insulation } \\
\text { panel }\end{array}$ & $\begin{array}{l}\text { Insulation properties (thermal } \\
\text { insulation) }\end{array}$ \\
\hline $\begin{array}{l}\text { Lysine from press- } \\
\text { pulp }\end{array}$ & $\begin{array}{l}\text { Lysine from glucose } \\
\text { syrup }\end{array}$ & Sugars-to-lysine productivity \\
\hline
\end{tabular}

1 ton $_{\mathrm{DM}}$ of biomass. Fig. 2 shows a Sankey diagram of the baseline scenario. Results for the other configuration scenarios are presented in the supporting information, SI-3.

From Fig. 2, it is possible to observe that the fractionation process mainly separates the soluble biomass components from the insoluble. Soluble components end up in the press-juice, while insoluble ones, such as lignin, cellulose and hemicellulose, mostly end up in the press-pulp. In the baseline scenario, approximately $70 \%$ of the DM ends up in the cake (press-pulp), 17\% in the protein-feed and $13 \%$ in the residuals. Approximately $40 \%$ of the protein available in the whole biomass is separated into the animal-grade protein. The animal-grade protein has a protein content of $46 \%{ }_{\mathrm{DM}}$ in the animal feed, which is similar to the protein content in soybean meal (Nemecek and Kägi, $2007)$ and in line with previous works ((Kamm et al., 2009). Of the remaining protein, approximately $55 \%$ is separated into the cake and $5 \%$ ends up in the residual liquid. It is important to note that a substantial part of the protein found in the cake is fiber-bound, and thereby can only be digested by ruminants, as it is impossible to separate this type of protein by mechanical means only (Dotsenko and Lange, 2016). Insoluble carbohydrates, fiber bound proteins, and lignin are the main components of the press-pulp, with carbohydrates making up the largest share of $62 \%$ press-pulp dry matter. Lignin accounts for $12 \%$ DM of the press-pulp, which accounts for $99 \%$ of the lignin content in the original biomass.

Table 5 shows the output of the GBR, from the conversion of 1 ton $_{\mathrm{DM}}$ in all configuration scenarios. The yield of animal-grade protein varies from $153 \mathrm{~kg} /$ ton $_{\mathrm{DM}}$ for scenarios $1 . \mathrm{B} .1$ and $1 . \mathrm{T} .2$, to $206 \mathrm{~kg} /$ ton $_{\mathrm{DM}}$ for the 2.T.1 scenario. In comparison to the baseline, the yield varies within a range of $-11 \%$ for the lowest yielding scenario to $+20 \%$ for the highest yielding one. The yield of animal-grade protein is similar for scenarios 1.B.1 and 1.T.2, however, a more advanced processing method allows for human-grade protein to be produced in 1.T.2, resulting in an overall protein output of $189 \mathrm{~kg}$. Press-pulp yield is only affected by the number of times fractionation is carried out. Pressing twice decreases the press-pulp yield by approximately $-6 \%$, while at the same time increasing the protein-feed yield by approximately $+18 \%$ compared to the baseline. Moreover, when 


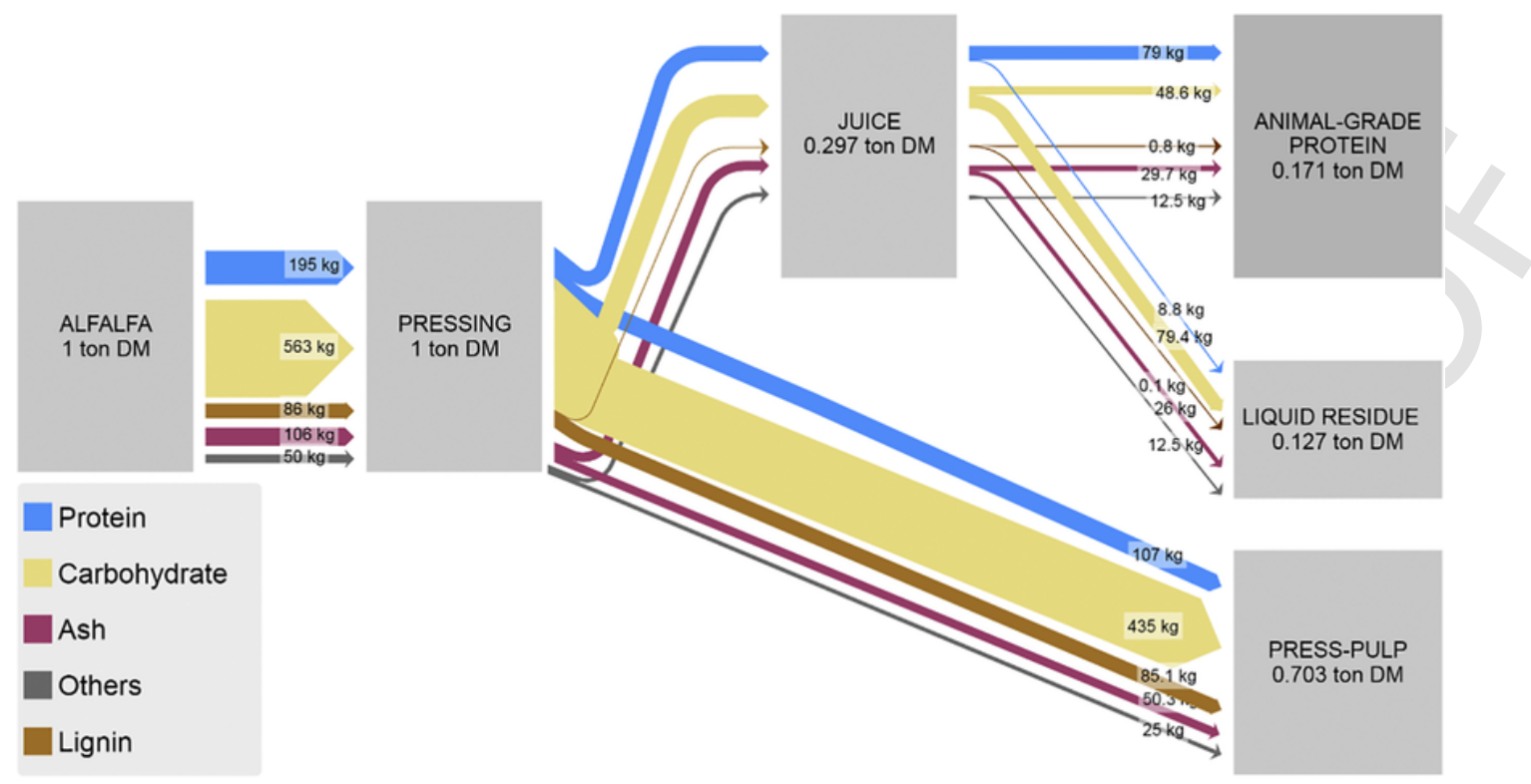

Fig. 2. The Sankey diagram shows, for the baseline scenario, how the biomass components are separated during the GBR process and the composition of the final GBR products.

Table 5

Breakdown of GBR product quantities in the different configuration scenarios from the PFS analysis. Amounts shown per 1tonDM of converted feedstock biomass.

\begin{tabular}{lllll}
\hline $\begin{array}{l}\text { Scenario } \\
\text { name }\end{array}$ & $\begin{array}{l}\text { Animal-grade } \\
\text { protein }[\mathrm{kg}]\end{array}$ & $\begin{array}{l}\text { Human-grade } \\
\text { protein }[\mathrm{kg}]\end{array}$ & $\begin{array}{l}\text { Press-pulp } \\
{[\mathrm{kg}]}\end{array}$ & $\begin{array}{l}\text { Residues } \\
{[\mathrm{kg}]}\end{array}$ \\
\hline $\begin{array}{c}\text { Baseline } \\
(1 . T .1)\end{array}$ & $1.71 * 10^{2}$ & {$[-]$} & $7.03 * 10^{2}$ & $1.27 \cdot 10^{2}$ \\
1.B.1 & $1.53 * 10^{2}$ & {$[-]$} & & \\
1.T.2 & $1.53 * 10^{2}$ & $3.55^{*} 10^{1}$ & $7.03 * 10^{2}$ & $1.44 * 10^{2}$ \\
2.T.1 & $2.06 * 10^{2}$ & {$[-]$} & $7.03 * 10^{2}$ & $1.09 * 10^{2}$ \\
2.B.1 & $1.80 * 10^{2}$ & {$[-]$} & $6.64 * 10^{2}$ & $1.31 * 10^{2}$ \\
2.T.2 & $1.80 * 10^{2}$ & $4.60 * 10^{1}$ & $6.64 * 10^{2}$ & $1.56 * 10^{2}$ \\
\hline
\end{tabular}

looking at the GBR residues, lowest output of residues is found when the two-step protein separation process is in place; i.e. in the 1.T.2 and 2.T.2 scenarios. On the other hand, the output of residues is highest when biological precipitation is used because of the lower efficiency of this process i.e. scenarios 1.B.1 and 2.B.1. The yield of GBR output is in line with previous publications (Kamm et al., 2009; O'Keeffe et al., 2011b).

Fig. 3 shows a detailed analysis of the protein distribution in the GBR products. In the baseline scenario, the overall protein extraction efficiency, i.e. the protein that ends up in the protein-rich feed, is ap-

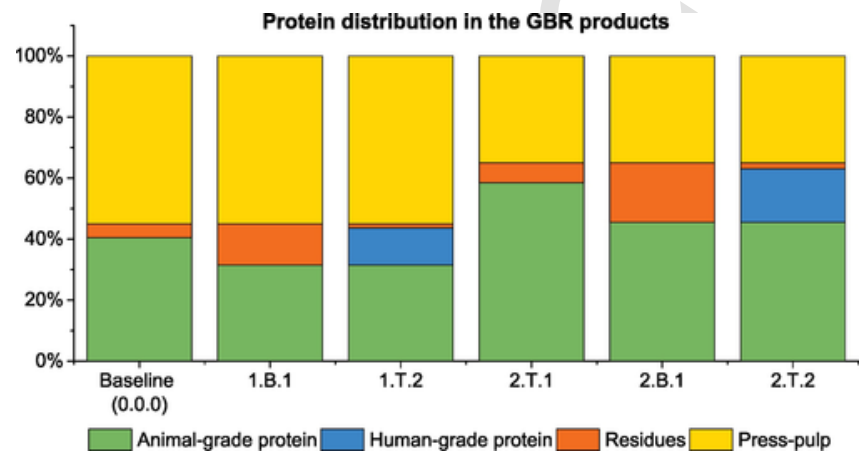

Fig. 3. PFS results: Protein distribution between the GBR products in the studied scenarios. proximately $41 \%$. By using biological coagulation, the overall protein extraction efficiency decreases to $32 \%$, while increasing the protein in the residues from $5 \%$ to $14 \%$. Contrastingly, using a two-step protein separation increases the protein extraction efficiency to $44 \% ; 32 \%$ in the animal-grade and $12 \%$ in the human-grade protein feed.

Two-step fractionation allows for an increase in the protein extraction efficiency of approximately $+18 \%$ for scenario $2 . T .1,+5 \%$ for scenario 2.B.1 and $+23 \%$ in scenario 2.T.2, compared to the baseline. Since more protein is extracted in the press-juice, the protein content in the press-pulp decreases. Thus, the protein content of the press-pulp drops from $15 \%{ }_{\mathrm{DM}}$ with one-step fractionation to $10 \%{ }_{\mathrm{DM}}$ with two-step (see Table SI-10). This results in a protein content lower than the minimum requirement for animal feed as stated by Kamm et al. (2010) of $140 \mathrm{~g} / \mathrm{kg}$. Hence, the utilization of the press-pulp as ruminant feed in the 2.X.X scenarios is excluded in the LCA results.

Table 6 shows substitution factors (SF) and biogas yields calculated for the LCA model from the PFS analysis. SFs for the animal-grade protein to soybean meal vary from 1.15 to $0.81 \mathrm{~kg} / \mathrm{kg}_{\text {soymeal }}$ depending on the GBR configuration scenario. The cake-silage SF is slightly below one when compared to alfalfa silage, because part of the protein originally available in the biomass has been removed into the press-juice, decreasing its nutritional value. When utilized as composite, all scenarios have a similar SF, since it is assumed that a reduction of protein and other soluble products in the press-pulp does not affect the thermal properties of the composite.

Table 6

PFS results: quality parameters for the LCA model.

\begin{tabular}{|c|c|c|c|c|c|c|c|}
\hline Parameter & Unit & 1.T.1 & 1.B.1 & 1.T.2 & 2.T.1 & 2.B. 1 & 2.T.2 \\
\hline SF animal protein & $\mathrm{kg} / \mathrm{kg}_{\mathrm{s}}$ & 0.95 & 0.81 & 0.81 & 1.15 & 1.01 & 1.01 \\
\hline SF human protein & $\mathrm{kg} / \mathrm{kg}_{\text {soymilk }}$ & {$[-]$} & {$[-]$} & 1.40 & {$[-]$} & {$[-]$} & 1.56 \\
\hline SF cake-silage & $\mathrm{kg} / \mathrm{kg}_{\text {silage }}$ & 0.96 & 0.96 & 0.96 & {$[-]^{1}$} & {$[-]^{1}$} & {$[-]^{1}$} \\
\hline SF cake-composite & $\mathrm{kg} / \mathrm{kg}_{\text {rockwool }}$ & 0.90 & 0.90 & 0.90 & 0.90 & 0.90 & 0.90 \\
\hline SF cake-lysine & $\mathrm{kg} / \mathrm{kg}_{\text {syrup }}$ & 0.79 & 0.79 & 0.79 & 0.84 & 0.84 & 0.84 \\
\hline Specific biogas yield ${ }^{2}$ & $\mathrm{~m}^{3} / \mathrm{kg}_{\mathrm{DM}}$ & 0.25 & 0.26 & 0.25 & 0.26 & 0.26 & 0.25 \\
\hline
\end{tabular}

${ }^{1}$ Excluded because the protein content of the press-pulp below the minimum nutritional threshold

${ }^{2}$ Based on Volatile Solid (VS) content of the residual fraction. 
For the fermentation utilization, the SF is correlated to the carbohydrate content in the press-pulp. Two-step fractionation increases the carbohydrate content per DM of press-pulp and thereby the SF for lysine increases.

The biogas yield has a very limited variation between the studied scenario and ranges from $+4 \%$ in scenario 2. B. 1 to $-1 \%$ in scenario 1.T.2. Specific biogas yields are in line with previous results found in the literature (Santamaría-Fernández et al., 2017).

\subsubsection{Energy consumption in the GBR}

Fig. 4 presents the GBR energy footprint in the different configuration scenario. The figure shows total heat and electricity consumption for each configuration scenario. Results are shown for the utilization scenario where the press-pulp substitute animal feed. Figs. SI-2 and SI-3 in the SI show the analysis for electricity and heat separately.

The total energy consumption in the GBR ranges from $399 \mathrm{MJ} /$ ton $_{\mathrm{DM}}$ in scenario $1 . \mathrm{B} .1$ to $1694 \mathrm{MJ} /$ ton $_{\mathrm{DM}}$ for scenario 2.T.2. The lower range of energy consumption is in line with results presented by Kamm et al. (2009), while the upper range is higher in this study due to differences in precipitation temperatures. While Kamm et al. (2009) takes into consideration a pre-heating step with recycled heat and lower precipitation temperature, which result in an overall lower energy consumption, the present study had one heating step with a precipitation temperature of $80^{\circ} \mathrm{C}$, which leads to the high energy consumption at the upper range. The most energy consuming process is the coagulation followed by drying and protein separation. Pressing the biomass twice increases the energy consumption by approximately $+45 \%$. However, the increase occurs in the precipitation step, as an extra washing step leads to a larger water content that has to be heated during thermal precipitation. Therefore, $38 \%$ of the added energy consumption is present during this step, while only $7 \%$ is due to the energy consumed in the additional fractionation process. Furthermore, the energy consumption of protein separation and drying shows a slight increase, due to the higher protein content of the press-juice. The use of biological precipitation, which requires a lower operating temperature, allows a reduction in energy consumption of $-65 \%$ for the 1. B. 1 and $-43 \%$ for the 2. B. 1 scenarios compared to the baseline. The energy produced by anaerobic digestion of the residues has a limited contribution since the Volatile Solid (VS) content available in this stream is very low. Part of the heat produced is used internally in the biogas plant to warm up the residues. For the most advanced scenario, i.e. 2.T.2, the energy produced from biogas does not offset the heat requirement in the biogas plant, resulting in an overall net heat consumption for processing the residues.

\section{2. $L C A$ results}

\subsubsection{LCA results baseline}

Fig. 5 shows midpoint LCA results for the baseline scenario. Negative values represent environmental savings, while positive values show burdens to the environment compared to the production of the conventional products. The net results are negative throughout the ICs, with the exception of Non-renewable energy (NRE), since the avoided production of conventional protein-feed, silage and energy replaced by GBR products, is associated with larger impacts than those induced by the GBR value chain. For NRE, the system has a positive score, which is connected to the agricultural inputs and the energy consumption in the biorefining process.

Savings related to substituted protein dominate the overall score for the freshwater ecotoxicity impact category (PFWTox IC) and are two orders of magnitude higher than the induced impacts from the agricultural and GBR steps. There are two reasons for this: (i) the feedstock biomass used in the biorefinery has lower pesticide application rates compared to highly industrialized crops like soy and corn/ maize that are substituted (ii) implications from the inventory modelling approach used for the pesticide emissions. For the biomass converted in the GBR (i.e. the induced impacts), PFWTox is modelled using PestLCI (Dijkman et al., 2012) to quantify the pesticide emissions at the field level (Parajuli et al., 2017b). In contrast, for the avoided crops (e.g. soy) the modelling approach is based on the EcoInvent guidelines, which assume that $100 \%$ of all pesticides applied to the field are emitted to the soil. It is not possible to apply the PestLCI model to the credited EcoInvent processes, since the avoided crops are grown outside Europe and the pesticide model cannot yet assess other geographical regions than Europe.

Looking at the induced impacts, the agricultural stage plays a major role, contributing with a range of $97 \%$ for Agricultural land occupation (ALO) to $48 \%$ for NRE. The biorefining stage shows high contribution in the energy related ICs, such as GWP and NRE, where it induces a total impact of $40 \%$ and $52 \%$, respectively for each IC.

Regarding the avoided impacts, i.e. the credits connected to the replacement of conventional products, the largest credits arise from the production of silage feed. This is due to the large yield (biomass-

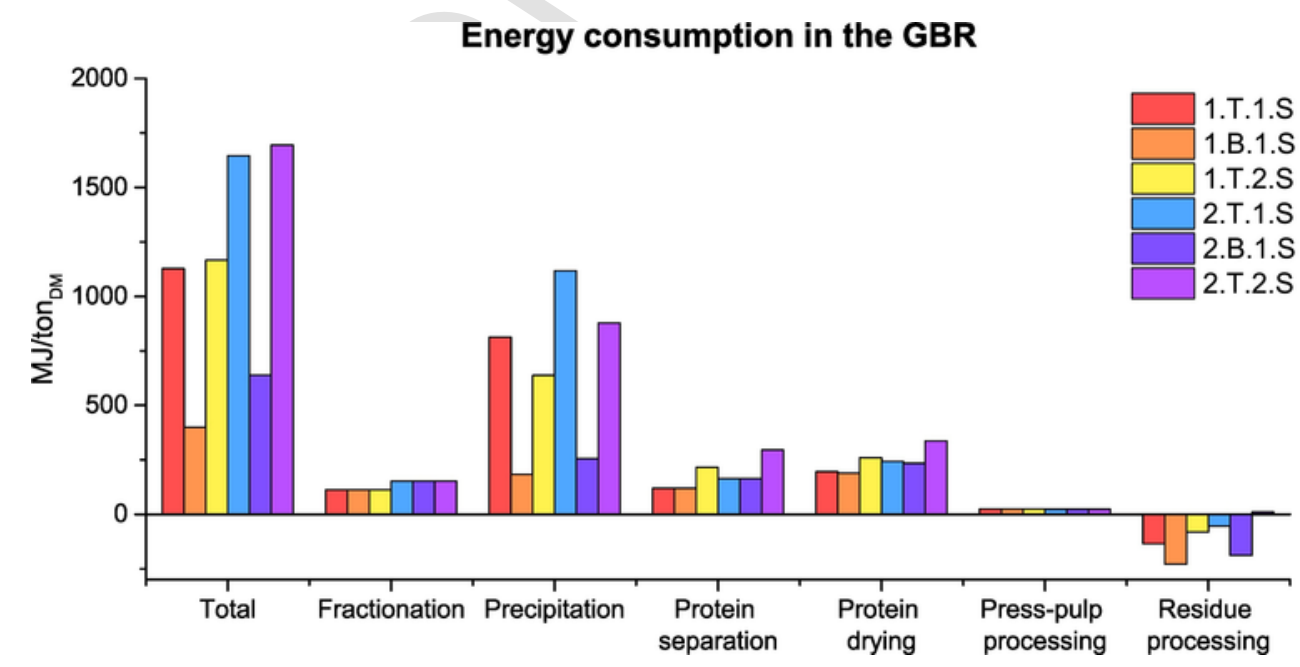

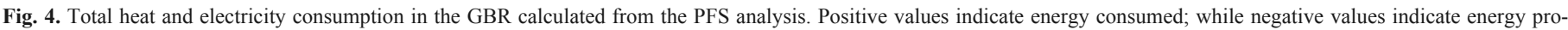
duced. 
LCA midpoint results: baseline scenario (1.T.1.S)
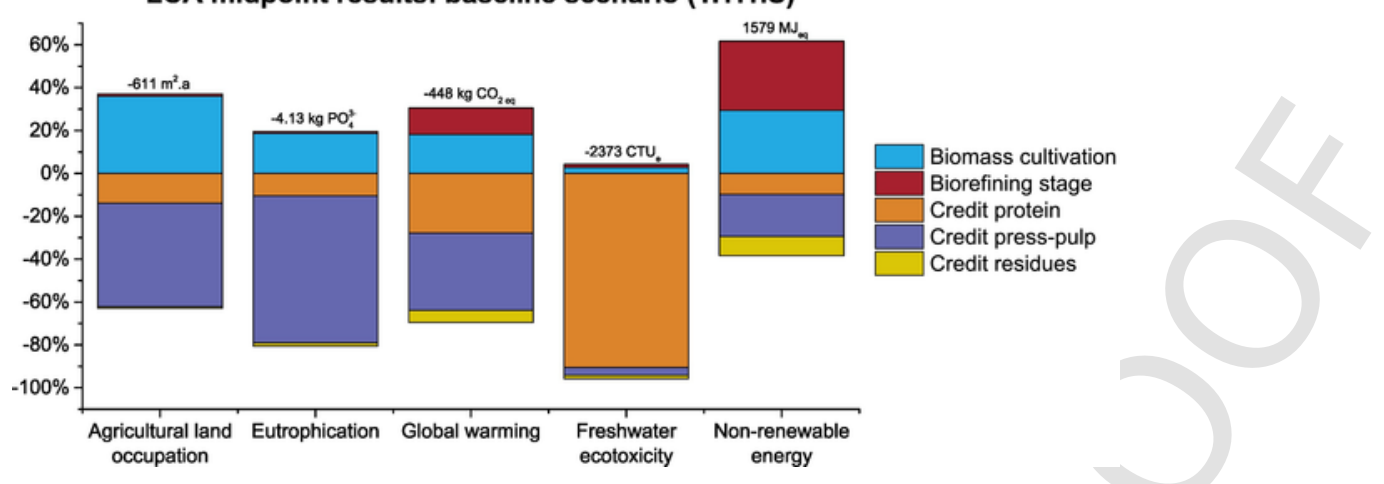

Fig. 5. Midpoint LCA results for the conversion of 1 ton $_{\mathrm{DM}}$ alfalfa for the baseline scenario (1.T.1.S). The figure shows the percentage contribution of each life cycle stage and the total score for each impact category.

to-product) of this product compared to the others products, as approximately $70 \%$ of the feedstock ends up as silage feed. Thus, the avoided impacts induce savings in the range of $-85 \%$ for EP and $-4 \%$ for PFWTox. For climate change, the protein product contributes $40 \%$ of the avoided impacts, demonstrating that the production of local, protein-rich feed alternatives to soybean meal can lead to a reduction of climate change related impacts.

\subsubsection{Utilization of the press-pulp}

Fig. 6 shows impacts of the baseline GBR configuration scenario (1.T.1) for different downstream utilizations of the press-pulp. A similar trend is observed for the other configuration scenarios (see SI-4).

The environmental performance of the system changes depending on the type of downstream application and consequently according to the type of avoided product. If the press-pulp is used for silage production, and thereby the avoided product is an agricultural product, the largest impact reduction potential can be achieved in the agricultural related impact categories, such as ALO and EP. If the press-pulp is used for the production of insulation panels, there are large reductions in the energy related impact categories, i.e. GWP and NRE, since the pulp based product replaces an energy intensive product. Thus, burden shifting is observed between the silage and insulation applications, since benefits for agriculturally related ICs are exchanged for burdens in the energy related ICs. Lastly, the best overall performance between the studied utilization scenarios occurs when the press-pulp is used for lysine production, where the net scores are below zero across all impact categories.

\subsubsection{GBR configuration}

LCA results of 15 different GBR scenarios are presented in Table 7. The 2.T.2.F scenario exhibit the best environmental performance in the ALO, EP (together with 1.B.1.S), GWP and PFWTox impact categories. For NRE, scenarios 2.T.2.C and 1.T.2.C have the lowest score. The worst performing scenarios are 1.B.1.C in ALO and EP, 1.T.1.S in GWP and NRE and 1.B.1.S in PFWTox.

Table 7 reveals a visible pattern and highlights the importance of protein recovery for the overall LCA results. It is evident, by observing the color pattern, that biorefinery configurations that prioritize protein extraction efficiency reach the largest savings across the ICs, as can be observed by looking at the scenario group X.X.2, which has two-step protein separation for all scenarios. Moreover, scenario 2.T.2 which has two-step fractionation and two-step protein separation and thereby has the highest protein recovery is the best performing scenario.

The following paragraphs describe the variation in the LCA results between baseline and alternative processes in each biorefining stage. Results are presented for the utilization scenario where the press-pulp is used for lysine production. A similar trend can be seen for the other utilization scenarios (see SI-4).

By using two-step fractionation and thereby increasing the protein content in the press-juice, savings are achieved throughout all ICs except for NRE, as shown in Fig. 7. The choice of fractionation frequency affects the system in three different ways: in the biorefining

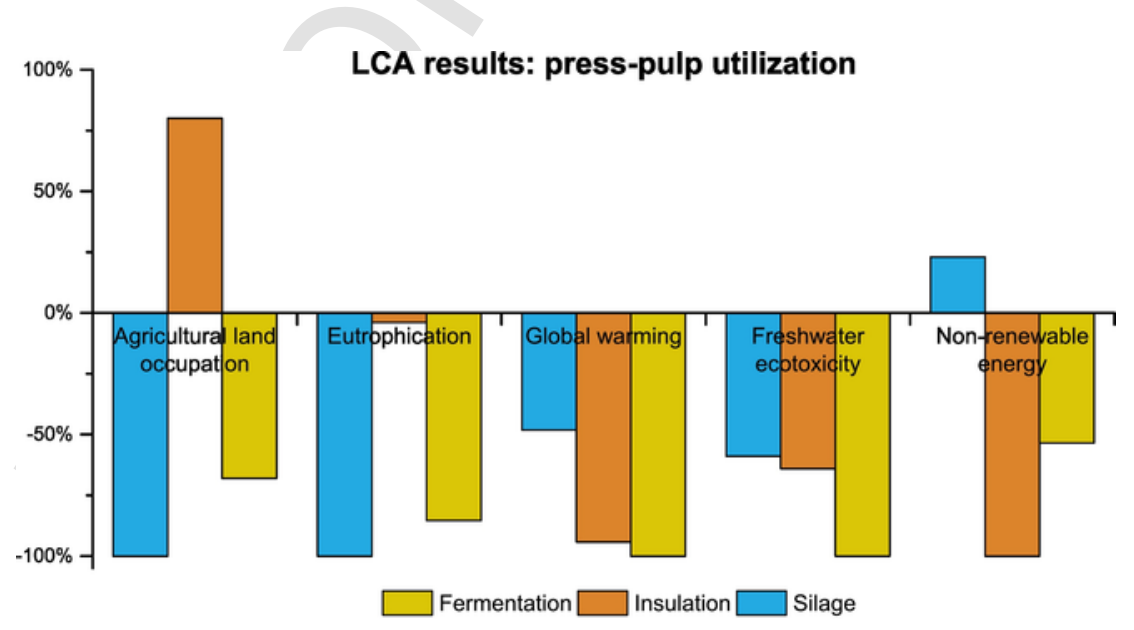

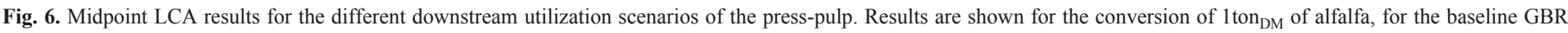
configuration and are internally normalized to show contributions relative to maximum savings. 
Table 7

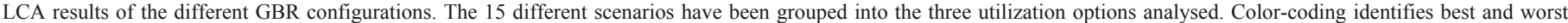
performing configuration scenario within each utilization scenario moving in gradients from green to red, respectively for each impact category and press-pulp utilization option.

\begin{tabular}{|c|c|c|c|c|c|c|c|}
\hline \multicolumn{8}{|c|}{ Press-pulp for silage production } \\
\hline Impact category & Unit & $0.0 .0 . S$ & $0.1 .0 . S$ & $0.0 .1 . S$ & 1.1.0.S & $0.0 .1 . S$ & 1.0.1.S \\
\hline Agricultural land occ. & $m^{2} a$ & $-6.11 * 10^{2}$ & $-5.38 * 10^{2}$ & $-7.36 * 10^{2}$ & {$[-]$} & {$[-]$} & {$[-]$} \\
\hline Eutrophication & $\mathrm{kg} \mathrm{PO}_{4}{ }^{3-}{ }_{\text {eq }}$ & $-4.12 * 10^{0}$ & $-3.98 * 10^{0}$ & $-4.48 * 10^{\circ}$ & {$[-]$} & {$[-]$} & {$[-]$} \\
\hline Global warming & $\mathrm{kg} \mathrm{CO}$ 2eq & $-4.44 * 10^{2}$ & $-4.27 * 10^{2}$ & $-6.70 * 10^{2}$ & {$[-]$} & {$[-]$} & {$[-]$} \\
\hline Freshwater ecotoxicity & $\mathrm{CTU}_{\mathrm{e}}$ & $-2.37 * 10^{3}$ & $-1.84 * 10^{3}$ & $-3.45 * 10^{3}$ & {$[-]$} & {$[-]$} & {$[-]$} \\
\hline Non-renewable energy & $\mathrm{MJ}_{\text {primary }}$ & $1.63 * 10^{3}$ & $9.66 * 10^{2}$ & $-6.07 * 10^{2}$ & {$[-]$} & {$[-]$} & {$[-]$} \\
\hline \multicolumn{8}{|c|}{ Press-pulp for composite material production } \\
\hline Impact category & Unit & $0.0 .0 . C$ & $0.1 .0 . \mathrm{C}$ & $0.0 .1 . \mathrm{C}$ & 1.0.0.C & 1.1.0.C & 1.0.1.C \\
\hline Agricultural land occ. & $\mathrm{m}^{2} \mathrm{a}$ & $4.89 * 10^{2}$ & $5.62 * 10^{2}$ & $3.67 * 10^{2}$ & $3.45 * 10^{2}$ & $4.50 * 10^{2}$ & $1.67 * 10^{2}$ \\
\hline Eutrophication & $\mathrm{kg} \mathrm{PO}_{4}{ }^{3-}{ }_{\text {eq }}$ & $-1.54 * 10^{-2}$ & $1.28 * 10^{-1}$ & $-3.66 * 10^{-1}$ & $-3.26 * 10^{-1}$ & $-1.20 * 10^{-1}$ & $-8.36 * 10^{-1}$ \\
\hline Global warming & $\mathrm{kg} \mathrm{CO}_{2 \text { eq }}$ & $-8.71 * 10^{2}$ & $-8.50 * 10^{2}$ & $-1.09 * 10^{3}$ & $-9.42 * 10^{2}$ & $-9.13 * 10^{2}$ & $-1.26 * 10^{3}$ \\
\hline Freshwater ecotoxicity & $\mathrm{CTU}_{\mathrm{e}}$ & $-2.58 * 10^{3}$ & $-2.05 * 10^{3}$ & $-3.66 * 10^{3}$ & $-3.65 * 10^{3}$ & $-2.88 * 10^{3}$ & $-5.21 * 10^{3}$ \\
\hline Non-renewable energy & $\mathrm{MJ}_{\text {primary }}$ & $-6.83 * 10^{3}$ & $-7.44 * 10^{3}$ & $-8.99 * 10^{3}$ & $-6.05 * 10^{3}$ & $-6.96 * 10^{3}$ & $-9.21 * 10^{3}$ \\
\hline \multicolumn{8}{|c|}{ Press-pulp as fermentation feedstock } \\
\hline Impact category & Unit & 0.0.0.F & 0.1.0.F & 0.0.1.F & 1.0.0.F & 1.1.0.F & 1.0.1.F \\
\hline Agricultural land occ. & $m^{2} a$ & $-3.92 * 10^{2}$ & $-3.20 * 10^{2}$ & $-5.40 * 10^{2}$ & $-5.39 * 10^{2}$ & $-4.34 * 10^{2}$ & $-7.43 * 10^{2}$ \\
\hline Eutrophication & $\mathrm{kg} \mathrm{PO}_{4}{ }^{3-}$ eq & $-3.46 * 10^{\circ}$ & $-3.32 * 10^{0}$ & $-3.87 * 10^{\circ}$ & $-3.80 * 10^{\circ}$ & $-3.60 * 10^{\circ}$ & $-4.37 * 10^{\circ}$ \\
\hline Global warming & $\mathrm{kg} \mathrm{CO}_{2 \text { eq }}$ & $-9.18 * 10^{2}$ & $-9.01 * 10^{2}$ & $-1.15 * 10^{3}$ & $-1.04 * 10^{3}$ & $-1.01 * 10^{3}$ & $-1.37 * 10^{3}$ \\
\hline Freshwater ecotoxicity & $\mathrm{CTU}_{\mathrm{e}}$ & $-3.85 * 10^{3}$ & $-3.32 * 10^{3}$ & $-5.11 * 10^{3}$ & $-4.94 * 10^{3}$ & $-4.17 * 10^{3}$ & $-6.68 * 10^{3}$ \\
\hline Non-renewable energy & $\mathrm{MJ}_{\text {primary }}$ & $-3.54 * 10^{3}$ & $-4.21 * 10^{3}$ & $-5.85 * 10^{3}$ & $-3.31 * 10^{3}$ & $-4.22 * 10^{3}$ & $-6.62 * 10^{3}$ \\
\hline
\end{tabular}

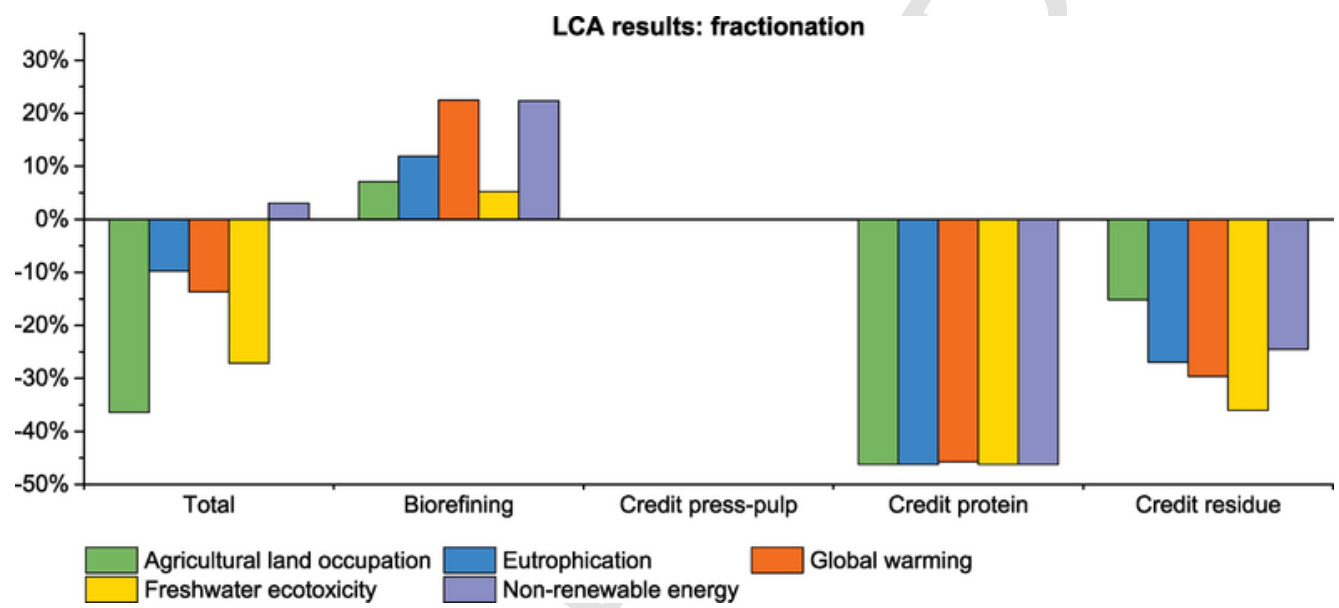

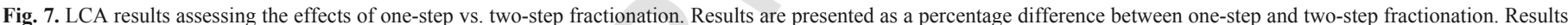
shows the difference on the total LCA score (first column) and on the affected processes (biorefining, credit press-pulp, credit protein and credit residues).

stage, in the savings obtained by replacing conventional protein feed and in the amount of biogas produced.

Firstly, two-step fractionation leads to higher impacts, since it increases energy consumption at the biorefining stage. However, this is counter-balanced by a higher yield of protein in the feed products and biogas, which leads to an overall lower impact score for the alternative scenario for all ICs except for NRE. Having one or two fractionation steps does not, however, change the fermentation potential of the press-pulp, since the cellulose and hemicellulose content in the press-pulp is not affected by this procedure. Hence, the savings connected to press-pulp utilization remain unaltered.

As with fractionation, the same life cycle stages are affected by the choice of precipitation method, however the trend is inverted when biological precipitation is employed, see Fig. 8. The use of biological precipitation induces higher environmental impacts across all ICs, except for NRE. Despite having lower energy consumption, biological precipitation has a lower overall protein precipitation efficiency. Hence, the reduction in energy consumption is not enough to counteract the reduction in product yield, resulting in a net overall impact increase in all IC, except for NRE, which is strongly reciprocal to energy consuming processes.

By using a two-step protein separation process, the production of a higher value product i.e. human-grade protein, is possible, which leads to a reduction in the environmental impacts of the GBR across all ICs, see Fig. 9. However, the GBR stage becomes more burdensome, due to higher energy consumption needed in the extra protein separation stage, and because a part of biogas credits are lost, since the residual juice has a lower VS content. On the other hand, the production of human protein fully counteracts the higher impacts induced in the other life cycle stages and results in a net overall impact reduction.

\subsubsection{Sensitivity analysis}

The results of the sensitivity analysis connected to the heat consumption in the GBR are presented in this paragraph and in Fig. 10. The NRE score ranges between $2480 \mathrm{MJ} /$ ton $_{\mathrm{DM}},+57 \%$ compared to the baseline, and $1479 \mathrm{MJ} /$ ton $_{\mathrm{DM}},-6 \%$ from the baseline. It can be observe that a variation of the parameter connected to heat optimization has larger effect when there is limited heat recycling. Further- 


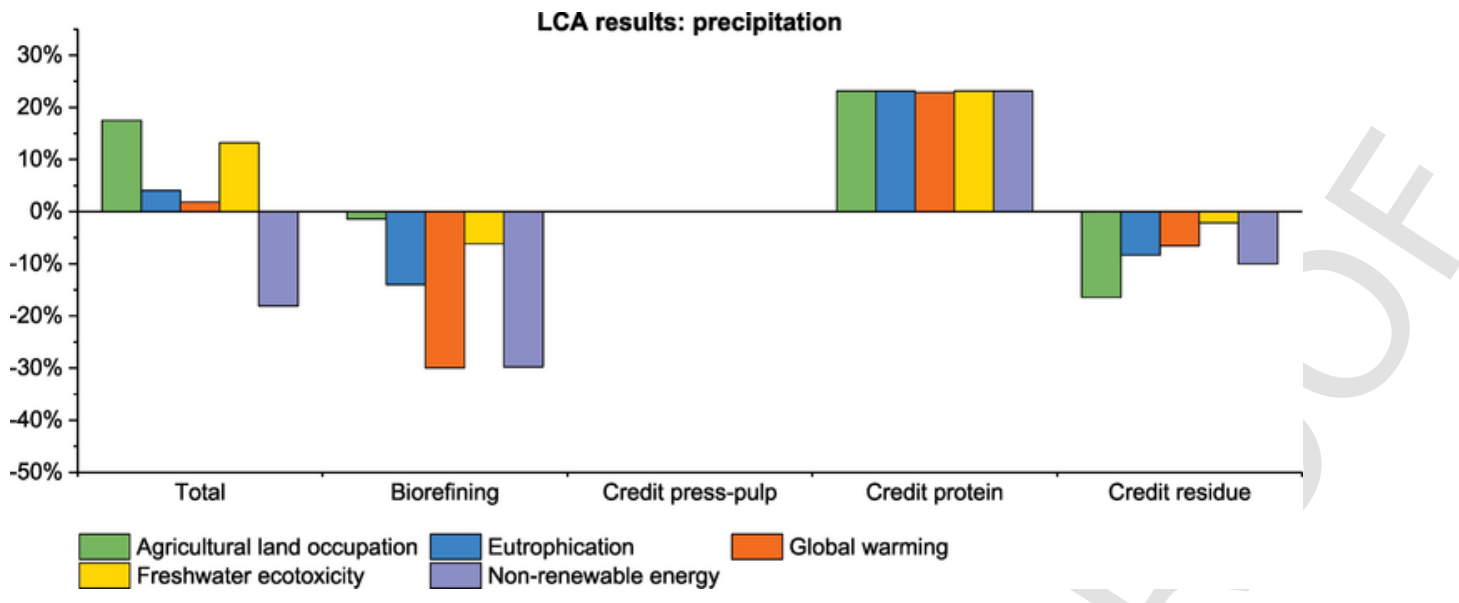

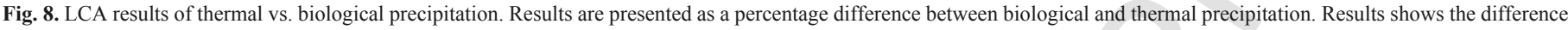
on the total LCA score (first column) and on the affected processes (biorefining, credit press-pulp, credit protein and credit residues).

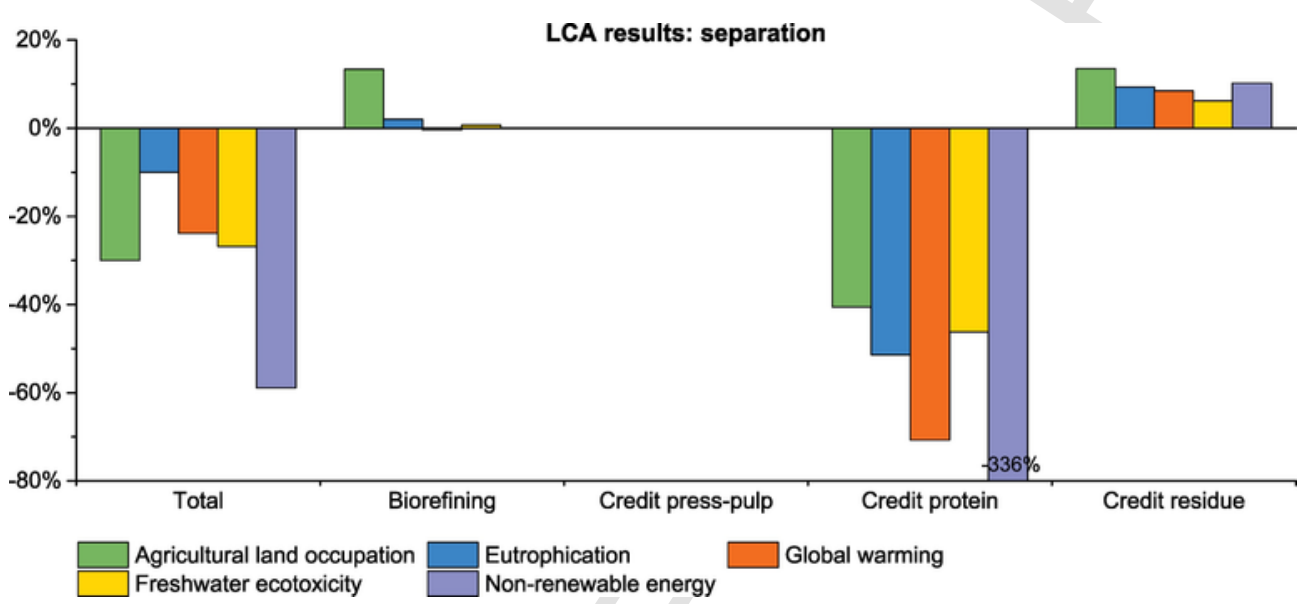

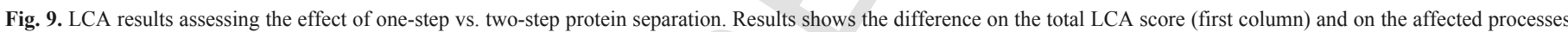
(biorefining, credit press-pulp, credit protein and credit residues).

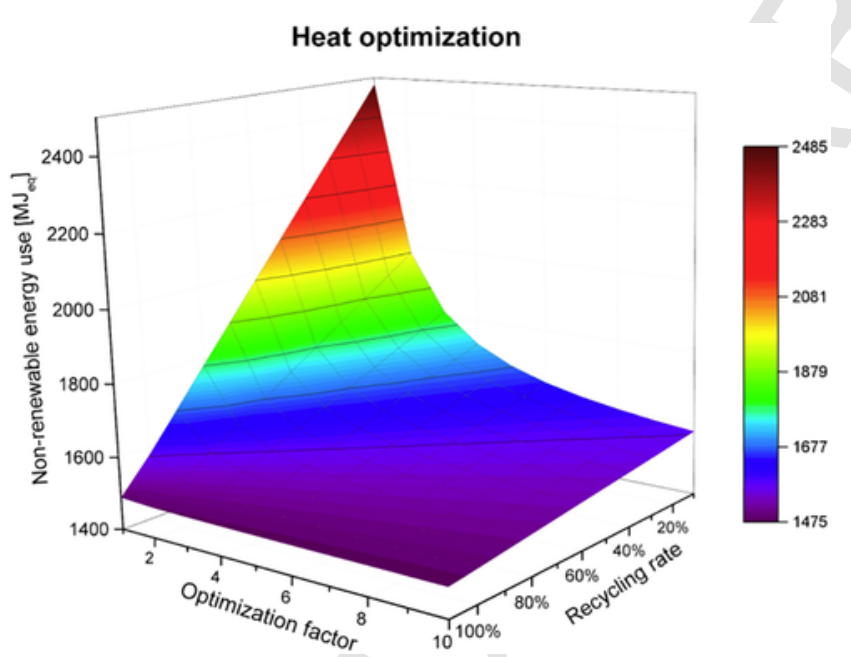

Fig. 10. Sensitivity analysis results for non-renewable energy. The figure shows the NRE score varying the parameters connected to the heat consumption in the GBR. The heat optimization parameter (x-axis) has been varied between 1 and 10 while the heat recycling (y-axis) has been varied between $0 \%$ and $100 \%$. more the NRE score is positive even in the most optimized scenario (i.e. optimization parameter $=10$ and $100 \%$ of heat recycling) suggesting that the GBR system still has a lower performance in this IC compared to the conventional products. As shown in (Corona et al., n.d.) this could be avoided by a different energy source for heat production, e.g. substituting natural gas with biomass or biogas.

\section{Conclusion}

Maximizing product yield proved to be the most important environmental optimization parameter for the GBR, even more important than reducing the biorefinery's energy consumption. This can be observed when the protein content of the products is increased by applying either two-step fractionation, advanced protein separation, or both. Decreasing the biomass-to-product ratio influences the credits gained by substituting conventional products, which in the case of scenario 2.T.2 counteracts the higher energy consumption. On the other hand, biological precipitation results in low protein yields, which cannot be counterbalanced by the reduction in the energy consumption, showing once more that focus in the designing phase should lie on increasing the efficiency of product recovery in order to attain a more sustainable biorefinery. However, this does not rule out biological precipitation as such, but instead suggests an optimization 
of the separation step after the biological precipitation e.g. using membrane technology.

The utilization of the press-pulp was shown to be another important optimization parameter with extensive influence on the environmental profile of the GBR system, since approximately $70 \%$ of the biomass ends up in the pulp. If the press-pulp is used to replace conventional energy-intensive materials e.g. mineral wool, large savings are achieved on energy related ICs (GWP and NRE), while if the replaced product is agricultural, large savings are observed on agriculture related ICs (ALO, EP).

Green biorefining is shown to be an interesting biorefining concept. Biorefining of green biomass is technically possible and can bring environmental savings, when compared to conventional production methods. However, those savings are very much determined by the processing involved in the conversion stages and on the cascade utilization of the different platform products. An insight in the environmental implications of the different products and GBR configurations is the first step that complemented with an economic assessment of profitability can bring about sustainable choices for future bio-production.

\section{Acknowledgements}

This article is written as part of a PhD study at the Department of Management Engineering, Technical University of Denmark DTU). The study is co-funded by the Bio-Value Platform (http://biovalue.dk), funded under the SPIR initiative by the Innovation Fund Denmark, case no: 0603-00522B.

\section{Appendix A. Supplementary data}

Supplementary data to this article can be found online at https:// doi.org/10.1016/j.scitotenv.2018.03.357.

\section{References}

Ambye-Jensen, M., Adamsen, A.P.S., 2015. Green Biorefinery Concept Producing Local Feed Protein - Feasibility Study and Comparison of Central vs. Decentral Implementation.

Anaya-Reza, O., Lopez-Arenas, T., 2017. Comprehensive assessment of the l-lysine production process from fermentation of sugarcane molasses. Bioprocess Biosyst. Eng. https://doi.org/10.1007/s00449-017-1766-2.

Andersen, M., Kiel, P., 2000. Integrated utilisation of green biomass in the green biorefinery. Ind. Crop. Prod. 11, 129-137. https://doi.org/10.1016/ S0926-6690(99)00055-2.

Bell, G., Schuck, S., Jungmeier, G., Wellisch, M., Felby, C., Jørgensen, H., Stichnothe, H., Clancy, M., De Bari, I., Kimura, S., van Ree, R., de Jong, E., Annevelink, B., Kwan, K., Torr, K., Spaeth, J., 2014. IEA Bioenergy Task42 Biorefining.

Bentsen, N.S., Felby, C., Ipsen, K.H., 2006. Energy balance of 2nd generation bioethanol production in Denmark. Denmark Dong Energy R. 45.

Biowert, 2014. Agriplast - NFPP 5050/400 HM FactSheet, (Brensbach, Germany).

Blonk Consultant, 2010. Environmental Impacts of Synthetic Amino Acid Production. Gouda, the Netherlands.

Bosselmann, A.S., Jensen, M.V., Gylling, M., 2015. Proteinforbrug i danske konventionelle og økologiske husdyrproduktioner. IFRO Udredning.

Buswell, A.M., Mueller, H.F., 1952. Mechanism of methane formation. Ind. Eng. Chem. 44, 550-552. https://doi.org/10.1021/ie50507a033.

Cherubini, F., Jungmeier, G., Wellisch, M., Willke, T., Skiadas, I., Van Ree, R., de Jong, E., 2009. Toward a common classification approach for biorefinery systems. Biofuels Bioprod. Biorefin. 3, 534-546. https://doi.org/10.1002/bbb.

Cong, R.-G., Termansen, M., 2016. A bio-economic analysis of a sustainable agricultural transition using green biorefinery. Sci. Total Environ. 571, 153-163. https:// doi.org/10.1016/j.scitotenv.2016.07.137.

Cong, R.-G., Stefaniak, I., Madsen, B., Dalgaard, T., Jensen, J.D., Nainggolan, D., Termansen, M., 2017. Where to implement local biotech innovations? A framework for multi-scale socio-economic and environmental impact assessment of green bio-refineries. Land Use Policy 68, https://doi.org/10.1016/j.landusepol.2017.07. 036 .
Corona, A., Parajuli, R., Ambye-jensen, M., Hauschild, M.Z., Birkved, M., n.d. Environmental Screening of Suitable Biomasses for Green Biorefinery Conversion. (Under Rev).

DCA, 2016. Biobased Green Protein. Danish Centre for Food and Agriculture, Aarhus University, Aarhus, Denmark.

Dijkman, T.J., Birkved, M., Hauschild, M.Z., 2012. PestLCI 2. 0: a second generation model for estimating emissions of pesticides from arable land in LCA. Int. J. Life Cycle Assess. 973-986. https://doi.org/10.1007/s11367-012-0439-2.

Dotsenko, G., Lange, L., 2016. Enzyme enhanced protein recovery from green biomass pulp. Waste Biomass Valoriz. https://doi.org/10.1007/s12649-016-9718-7.

Ecker, J., Schaffenberger, M., Koschuh, W., Mandl, M., Böchzelt, H.G., Schnitzer, H., Harasek, M., Steinmüller, H., 2012. Green biorefinery upper Austria - pilot plant operation. Sep. Purif. Technol. 96, 237-247. https://doi.org/10.1016/j.seppur.2012. 05.027 .

Environdec, 2015. The EPD method. WWW Document http://www.environdec.com/ $\mathrm{sv} /$.

Eriksen, J., Nordemann, P., Og, J., Jacobsen, B.H., 2014. Virkemidler til realisering af 2. generations vandplaner og målretter arealregulering. Aarhus.

Fargione, J.E., Hill, J., Tilman, D., Polansky, S., Hawthorne, P., 2008. Land clearing and the biofuel carbon debt. Science 319 (80), 1235-1238. https://doi.org/10.1126/ science. 1245938 .

Grabowski, S., Boye, J.I., 2012. Green technologies in food dehydration. In: Boye, J.I., Arcand, Y. (Eds.), Green Technologies in Food Production and Processing. Springer US, Boston, MA, pp. 413-441. https://doi.org/10.1007/ 978-1-4614-1587-9_15.

Gylling, M., Jørgensen, U., Bentsen, N.S., Kristensen, I.T., Dalgaard, T., Felby, C., Larsen, S., Johannsen, V.K., 2016. The +10 million tonnes study. Frederiksberg. https://doi.org/10.13140/RG.2.2.12219.62247.

Hamelin, L., Naroznova, I., Wenzel, H., 2014. Environmental consequences of different carbon alternatives for increased manure-based biogas. Appl. Energy 114, 774-782. https://doi.org/10.1016/j.apenergy.2013.09.033.

Hermansen, J.E., Jørgensen, U., Lærke, P.E., Manevski, K., Jensen, S.K., Weisbjerg, M.R., Dalsgaard, T.K., Asp, T., Amby-jensen, M., Aage, C., Sørensen, G., Jensen, V., Gylling, M., Lindedam, J., Lübeck, M., Erik, O.G., 2017. Green Biomass: Protein Production through Bio-Refining Green Biomass. DCA - Danish Centre for Food and Agriculture, Aarhus, Denmark.

Hörtenhuber, S.J., Lindenthal, T., Zollitsch, W., 2011. Reduction of greenhouse gas emissions from feed supply chains by utilizing regionally produced protein sources: the case of Austrian dairy production. J. Sci. Food Agric. 91, 1118-1127. https://doi.org/10.1002/jsfa.4293.

Huijbregts, M.A.J., Steinmann, Z.J.N., Elshout, P.M.F., Stam, G., Verones, F., Vieira, M., Van Zelm, R., 2015. ReCiPe 2015: a Life Cycle Impact Assessment Method a Midpoint and Endpoint Level Report I: Characterisation Factors. Department of Environmental Science, Radboud University Nijmegen.

Jørgensen, U., Lærke, P.E., 2016. Perennial grasses for sustainable European protein production. In: Barth, S., Murphy-Bokern, D., Kalinina, O., Taylor, G., Jones, M (Eds.), Perennial Biomass Crops for a Resource-Constrained World. Springer International Publishing, Cham, pp. 33-41. https://doi.org/10.1007/ 978-3-319-44530-4_3.

Jørgensen, K., Hummelmose, A.B., Pedersen, B.K., Wøyen, T.T., Mægaard, E., Ruun, L.K., 2011. Budgetkalkuler 2010-pr. oktober 2010. Aarhus, Denmark, SEGES.

JRC, 2011. Recommendations for life cycle impact assessment in the European context - based on existing environmental impact assessment models and factors. In: ILCD Handb. Int. Ref. Life Cycle Data Syst. https://doi.org/10.278/33030.

Kamm, B., 2013. Introduction of biomass and biorefineries. In: Xie, H., Gathergood, N. (Eds.), The Role of Green Chemistry in Biomass Processing and Conversion. John Wiley \& Sons, Inc., pp. 1-26.

Kamm, B., Schönicke, P., Kamm, M., 2009. Biorefining of green biomass - technical and energetic considerations. CLEAN - Soil Air Water 37, 27-30. https://doi.org/ $10.1002 /$ clen. 200800122

Kamm, B., Hille, C., Schönicke, P., Dautzenberg, G., 2010. Green biorefi nery demonstration plant in Havelland (Germany). Biofuels Bioprod. Biorefin. 253-262. https: //doi.org/10.1002/bbb.218.

Kamm, B., Schönicke, P., Hille, C., 2016. Green biorefinery - industrial implementation. Food Chem. 197, 1341-1345. https://doi.org/10.1016/j.foodchem.2015.11. 088 .

Kragbæk, D.J.V., 2014. Protein Yields and Amino Acid Characterization of Juice and Pulp from White Clover, Red Clover, Lucerne and Ryegrass. Aarhus Univeristy, Aarhus, Denmark.

Kromus, S., Wachter, B., Koschuh, W., Mandl, M., Krotscheck, C., Narodoslawsky, M., 2004. The green biorefinery Austria - development of an integrated system for green biomass utilization. Chem. Biochem. Eng. Q. 18, 7-12.

Kromus, S., Kamm, B., Kamm, M., Fowler, P., 2006. Green Biorefineries the Green Biorefinery Concept - Fundamentals and Potential.

Larsen, J., Haven, , Thirup, L., 2012. Inbicon makes lignocellulosic ethanol a commercial reality. Biomass Bioenergy 46, 36-45. https://doi.org/10.1016/j.biombioe. 2012.03.033 
Lehuger, S., Gabrielle, B., Gagnaire, N., 2009. Environmental impact of the substitution of imported soybean meal with locally-produced rapeseed meal in dairy cow feed. J. Clean. Prod. 17, 616-624. https://doi.org/10.1016/j.jclepro.2008.10.005.

Leiß, S., Venus, J., Kamm, B., 2010. Fermentative production of L-lysine-L-lactate with fractionated press juices from the green biorefinery. Chem. Eng. Technol. 33, 2102-2105. https://doi.org/10.1002/ceat.201000314.

Mujumdar, A.S., 2014. Handbook of Industrial Drying, 4th ed CRC press.

Nemecek, T., Kägi, T., 2007. Life Cycle Inventories of Agricultural Production Systems, (Zurich and Dubendorf).

OECD, 2008. Economic assessment of biofuel support policies. Dir. Trade. Agric. Econ. 1-119. https://doi.org/10.1787/9789264050112-en.

O'Keeffe, S., Schulte, R.P.O., Lalor, S.T.J., O'Kiely, P., Struik, P.C., 2011. Green biorefinery (GBR) scenarios for a two-cut silage system: investigating the impacts of sward botanical composition, $\mathrm{N}$ fertilisation rate and biomass availability on GBR profitability and price offered to farmers. Biomass Bioenergy 35, 4699-4711. https://doi.org/10.1016/j.biombioe.2011.06.051.

O'Keeffe, S., Schulte, R.P.O., Sanders, J.P.M., Struik, P.C., 2011. I. Technical assessment for first generation green biorefinery (GBR) using mass and energy balances: scenarios for an Irish GBR blueprint. Biomass Bioenergy 35, 4712-4723. https:// doi.org/10.1016/j.biombioe.2011.06.017.

O'Keeffe, S., Schulte, R.P.O., Sanders, J.P.M., Struik, P.C., 2012. II. Economic assessment for first generation green biorefinery (GBR): scenarios for an Irish GBR blueprint. Biomass Bioenergy 41, 1-13. https://doi.org/10.1016/j.biombioe.2011. 11.018 .

Parajuli, R., Dalgaard, T., Jørgensen, U., Peter, A., Adamsen, S., Knudsen, M.T., Birkved, M., Gylling, M., Schjørring, J.K., 2015. Biorefining in the prevailing energy and materials crisis: a review of sustainable pathways for biorefinery value chains and sustainability assessment methodologies. Renew. Sust. Energ. Rev. 43, 244-263. https://doi.org/10.1016/j.rser.2014.11.041.

Parajuli, R., Knudsen, M.T., Birkved, M., Djomo, S.N., Corona, A., Dalgaard, T., 2017. Environmental impacts of producing bioethanol and biobased lactic acid from standalone and integrated biorefineries using a consequential and an attributional life cycle assessment approach. Sci. Total Environ. 598, 497-512. https:// doi.org/10.1016/j.scitotenv.2017.04.087.

Parajuli, R., Knudsen, M.T., Djomo, S.N., Corona, A., Birkved, M., Dalgaard, T., 2017. Environmental life cycle assessment of producing willow, alfalfa and straw from spring barley as feedstocks for bioenergy or biorefinery systems. Sci. Total Environ. 586, 226-240. https://doi.org/10.1016/j.scitotenv.2017.01.207.

Santamaría-Fernandez, M., Molinuevo-Salces, B., Kiel, P., Steenfeldt, S., Uellendahl, H., Lübeck, M., 2017. Lactic acid fermentation for refining proteins from green crops and obtaining a high quality feed product for monogastric animals. J. Clean. Prod. 162, 875-881. https://doi.org/10.1016/j.jclepro.2017.06.115.

Santamaría-Fernández, M., Molinuevo-Salces, B., Lübeck, M., Uellendahl, H., 2017. Biogas potential of green biomass after protein extraction in an organic biorefinery concept for feed, fuel and fertilizer production. Renew. Energy https://doi.org/10. 1016/j.renene.2017.03.012.

Schmidt, J.H., Weidema, B.P., Brandão, M., 2015. A framework for modelling indirect land use changes in life cycle assessment. J. Clean. Prod. 99, 230-238. https://doi. org/10.1016/j.jclepro.2015.03.013.

Searchinger, T., Heimlich, R., Houghton, R.A., Dong, F., Elobeid, A., Fabiosa, J., Tokgoz, S., Hayes, D., Yu, T.-H., 2008. Use of U.S. croplands for biofuels increases greenhouse gases through emissions from land-use change. Science 319 (80), 1238-1240. https://doi.org/10.1126/science.1151861.

Sharma, Hss., Mandl, M., 2014. Green biorefinery. Sustain. Bioenergy Prod. 535-564. https://doi.org/10.1201/b16764-30.

Sinclair, S., 2009. Protein extraction from pasture. Literature review part a: the plant fractionation bio-process and adaptability to farming systems. In: Milestone Rep. Prep. MAF SFF Grant C.

Termansen, M., Gylling, M., Jørgensen, U., Hermansen, J., Han-, L.B., Knudsen, M.T., Adamsen, A.P.S., Ambye-jensen, M., Jensen, V., Jensen, S.K., Andersen, H.E., Gyldenkærne, S., 2016. Green Biomass. DCA - Danish Centre for Food and Agriculture, Aarhus, Denmark.

Wang, Z., Solem, C., Jensen, P.R., n.d. Lysine Production From Geeen Biomass Press-pulp. (In Prepapration).

Wernet, G., Bauer, C., Steubing, B., Reinhard, J., Moreno-Ruiz, E., Weidema, B. 2016. The ecoinvent database version 3 (part I): overview and methodology. Int. J. Life Cycle Assess. 21, 1218-1230. https://doi.org/10.1007/s11367-016-1087-8.

Worldwatch Institute, 2006. Biofules for Transportation: Global Potential and Implications for Sustainable Agriculture and Energy in the 21st Century.

Xiu, S., Shahbazi, A., 2015. Development of green biorefinery for biomass utilization: a review. Trends Renew. Energy 1, 4-15. https://doi.org/10.17737/tre.2015.1.1. 008 . 